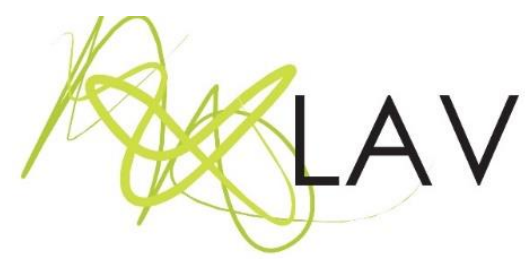

\title{
A professora Frida Kahlo: cores para uma (est)ética da docência
}

Teacher Frida Kahlo: colors for an (aesth)ethics of teaching

La maestra Frida Kahlo: colores para una (est)ética de la enseñanza

Odailso Sinvaldo Bertéi

Universidad Iberoamericana Ciudad de México

Universidade Federal de Santa Maria (UFSM)

\begin{abstract}
Resumo
Este estudo objetiva relacionar diferentes perspectivas conceituais, da educação da cultura visual, da filosofia foucaultiana e da pedagogia freireana, para pensar uma estética da docência no ensino das artes a partir das práticas docentes de Frida Kahlo. Através da metodologia investigativa da bricolagem, em seu intento de friccionar diferentes conceitos, articula-se uma trama epistemológica interdisciplinar. Os conceitos de estética da existência e de boniteza e decência da docência possibilitam interpretar os modos como Frida Kahlo instigava a autonomia criativa dos seus alunos e, por sua vez, isto nos possibilita pistas para o ensino das artes na contemporaneidade.
\end{abstract}

Palavras chave: estética da docência, ensino de arte, autonomia, Frida Kahlo

\begin{abstract}
This study aims to relate different conceptual perspectives, from visual culture education, Foucaultian philosophy and Freirean pedagogy, to think of an aesthetics of teaching in the teaching of the arts from the teaching practices of Frida Kahlo. Through the investigative methodology of bricolage, in its attempt to rub different concepts, an interdisciplinary epistemological plot is articulated. The concepts 'aesthetics of existence' and 'beauty and decency of teaching' make it possible to interpret the ways in which Frida Kahlo instigated the creative autonomy of her students and, in its turn, it provides us with clues for the teaching of the arts at the present time.
\end{abstract}

Keywords: aesthetics of teaching, teaching of the arts, autonomy, Frida Kahlo

\section{Resumen}

Este estudio tiene por objeto relacionar diferentes perspectivas conceptuales, la educación de la cultura visual, la filosofía foucaultiana y la pedagogía freiriana, para pensar una estética de la enseñanza de las artes a partir de las prácticas docentes de Frida Kahlo. A través de la metodología investigativa del bricolaje, en su intento de tensionar diferentes conceptos, se articula una trama epistemológica interdisciplinaria. Los conceptos de estética de la existencia, y de belleza y decencia de la docencia posibilitan interpretar las maneras con las que Frida Kahlo estimulaba

Revista Digital do LAV - Santa Maria - vol. 11, n. 1, p. 54-82- jan./abr. 2018 ISSN 1983 - 7348 http://dx.doi.org/10.5902/1983734831479 
la autonomía creativa de sus alumnos y a su vez, esto nos arroja pistas para la enseñanza de las artes en la contemporaneidad.

Palabras clave: estética de la docencia, enseñanza del arte, autonomía, Frida Kahlo.

Apesar da massiva propagação da vida e obra de Frida Kahlo (1907-1954) pelo mundo, pouco se tem estudado sobre seus processos criativos e sobre sua prática docente. Estes têm sido meus focos de interesse em torno dessa criadora. Frida Kahlo foi professora de pintura na Escuela de Pintura y Escultura de la Secretaria de Educación Pública "La Esmeralda" e realizou instigantes experiências criativas e pedagógicas com seus alunos, calcadas nas correlações arte e vida, criação artística e atuação sócio-política. E este é, portanto, o enfoque do presente estudo: refletir sobre determinados elementos da atuação docente de Frida Kahlo, especulando acerca de uma (est)ética da docência a partir de reflexões da educação da cultura visual e das concepções de estética da existência de Michel Foucault (1995; 2017) e de boniteza e decência da docência de Paulo Freire (2007). Em vez de equivalências, busco criar tensões, relações e reflexões entre essas que são diferentes teorias que tenho à mão enquanto pesquisador bricoleur (KINCLELOE; BERRY, 2007).

Importa-me, interessa-me e instiga-me olhar para os processos pedagógicos de Frida Kahlo com o auxílio de diferentes perspectivas, pois, com isso, penso ampliar as formas de compreensão e de construção de conhecimento sobre esse tema. Movimento de pensamento, adesão e paixão filosófica pela diferença, pelos diferentes modos de ver. Esse exercício de reflexividade e tática bricoladora possibilita borrar as fronteiras correntistas que, por vezes, impedem diálogos reflexivos entre tempos, visões e linhas de pensamento diferentes, como se os autores, pensadores e filósofos tivessem construído seus conceitos como cercas anuladoras do diálogo e da reflexão. Interpelando os modos objetivistas e monológicos de pesquisa, aciono táticas bricoladoras interpretativas e transito entre os prefixos "pré" e "pós" como corpo que, tendo em vista seu objeto de estudo, se relaciona com diferentes teorias representações, criações, visões - críticas e pós-críticas, para, com esse (mo)ver-se entre, construir formas de pensar, relacionar, criar, construir, refletir.

Freire e Foucault não se combatem e tampouco se apaziguam. Antes sim, cada um em seu tempo-espaço e comunidade conceitual, reflete sobre a ética. Foucault sobre uma vida bela fundamentada no agir ético e Freire sobre uma docência bonita fundamentada no agir ético. Como a própria Frida Kahlo é uma artista que não permite paragens de sossegos conceituais para compreender seus fazeres e posturas,

Revista Digital do LAV - Santa Maria - vol. 11, n. 1, p. 54-82- jan./abr. 2018 ISSN 1983 - 7348 http://dx.doi.org/10.5902/1983734831479 
persigo modos tensivos de refletir com a diferença, como corpo que implica sua subjetividade naquilo que diz e nos arranjos conceituais que faz para organizar seu dizer. Sou corpo que convoca as formas de ver de Freire, Foucault e outros autores para construir suas próprias formas de ver, analisar, pensar sobre o ensino das artes na contemporaneidade com as práticas docentes de Frida Kahlo.

\section{A dama das flores na Escola La Esmeralda}

Entre os anos 1943 a 1945, Frida Kahlo foi professora de iniciação à pintura (taller de Iniciación Pictórica), na Escuela de Pintura y Escultura de la Secretaria de Educación Pública "La Esmeralda", fundada oficialmente no ano de 1943 (MORENO, 2015). O surgimento e a necessidade de uma escola de ensino de arte como La Esmeralda se inscreveu em um importante momento histórico de efervescência política e cultural no México. Conforme reflete Reyes (2005), sua contribuição para a pedagogia da arte foi e ainda é imprescindível. O fato que legou o nome de "La Esmeralda" para esta instituição se refere à sua localização original, junto à pequena Rua Esmeralda, ou, melhor dizendo, o Beco Esmeralda. Por isso, a referida escola ficou carinhosamente conhecida como Escuela "La Esmeralda". Hoje, a atual Escuela Nacional de Pintura, Escultura y Grabado La Esmeralda está localizada no Centro Nacional de las Artes (CNA), um complexo artístico e cultural que abriga aulas, cursos, centros de investigação, centro multimídia, salas de exibição, teatro, espaços expositivos e a Biblioteca de las Artes. Além da Escola La Esmeralda, o CNA abriga a Escola de Arte Teatral, a Escola de Dança Clássica e Contemporânea, a Escola Superior de Música e o Centro de Capacitação Cinematográfica.

A Escola La Esmeralda conta hoje com os Cursos Licenciatura en Artes Visuales ${ }^{1}$ e Licenciatura en Docencia de las Artes $^{2}$, além de programas e ações de difusão cultural, oficinas abertas e demais projetos acadêmicos. Frida Kahlo e Los Fridos apelido dado ao grupo de alunos mais próximos da artista -, que foram parte da

\footnotetext{
${ }^{1}$ Conforme seu plano de estudos, o Curso de Licenciatura en Artes Visuales busca formar profissionais em Artes Visuais, artistas e produtores, tanto nos campos e técnicas tradicionais como nos emergentes e relacionados à tecnologia, integrando-se a instituições educativas, editoriais, museus, arquivos, grupos artísticos e projetos sociais. Plano de Estudos do Curso de Licenciatura en Artes Visuales disponível em: $<$ https://docs.wixstatic.com/ugd/d50bce 1fcf6b4061d74c1399e6124f2d24b26c.pdf>. Acesso em 11 mar. 2018.

${ }^{2}$ Conforme seu plano de estudos, o Curso de Licenciatura en Docencia de las Artes busca nivelar e regularizar a formação de professores de arte dos níveis médio e superior, assegurando sua permanência e desenvolvimento profissional nas instituições educativas que trabalham. Plano de Estudos do Curso de Licenciatura en Docencia de las Artes disponível em: $<$ https://docs.wixstatic.com/ugd/d50bce da532b2fd39d4b7aa3b7aa8171ec4057.pdf>. Acesso em 11 mar. 2018.
}

Revista Digital do LAV - Santa Maria - vol. 11, n. 1, p. 54-82 - jan./abr. 2018 ISSN 1983 - 7348 http://dx.doi.org/10.5902/1983734831479 
história dessa escola, são, junto a tantos outros artistas, pesquisadores e professores, uma referência no desenvolvimento da educação artística no México.

No período pós-revolucionário do México, diferentes artistas mexicanos buscaram abrir as portas da formação nas artes a todos que buscavam na expressão visual e plástica uma forma de compromisso para incidir no contexto sociocultural. A estes sujeitos pode-se compreender como "artistas que, na contramão dos sistemas tradicionais de ensino das questões estéticas, decidiram inocular as novas gerações de potenciais criadores"3 (JUÁREZ, 2005, p. 11, tradução do autor). Seu engajado compromisso com a arte e com a sociedade os levaram a contribuir de modo eficaz na formação artística de diferentes grupos de jovens aprendizes.

Diego Rivera, María Izquierdo, Benjamin Péret, Francisco Zuñiga e Frida Kahlo são alguns dos criadores que atenderam ao chamado do pintor, e então diretor da Escola La Esmeralda, Antonio Ruiz (1892-1964), conhecido como "El Corcito". Eles e elas juntaram-se a esse projeto de ensino que preconizava a aprendizagem de arte através da liberdade e da espontaneidade, distanciando-se do academicismo que predominava nos liceus tradicionais. Em comunhão com as ideias do diretor Antonio Ruiz e com a filosofia da Escola, no ano de 1943, a conhecida artista Frida Kahlo tornou-se parte do corpo docente da Escola La Esmeralda.

Zavala (2005, p. 25, tradução do autor) comenta que, segundo o grupo de alunos mais próximos de Kahlo, Los Fridos, Fanny Rabel (1922-2008), Arturo García Bustos (1926-2017), Guillermo Monroy Becerril (1924) e Arturo Estrada Hernández (1925), estas foram expressões dos ideários de Frida Kahlo em seu fazer docente: "A arte de pintar se aprende praticando." "É preciso ir ao encontro da vida para pintá-la." "Eu ainda sigo aprendendo a pintar." "Eu não os corrigirei tirando o lápis ou o pincel da sua mão. Vocês mesmos reconhecerão suas falhas" ${ }^{\prime 4}$. É instigante especular sobre como essas ideias e práticas podem ter caracterizado sua experiência docente, perpassado relações de ensinar e aprender, de amizade e cumplicidade entre ela e seus alunos como podem suscitar pistas e perguntas para o ensino das artes que hoje vivenciamos, como professores, estudantes e pesquisadores.

\footnotetext{
${ }^{3}$ No original: "[...] artistas que, a contracorriente de los sistemas tradicionales de enseñanza en tema estético, decidieron inocular a nuevas generaciones de potenciales creadores $[\ldots]$ ".

${ }^{4}$ No original: "El arte de pintar se aprende ejerciéndolo". "Hay que ir al encuentro de la Vida para pintarla". "Yo aún sigo aprendiendo a pintar". "Yo no corregiré quitando su lápiz de la mano. Ustedes mismos reconocerán suas fallas".
} 
Ao recordar de quando conheceu a professora Frida Kahlo, Fanny Rabel, a única moça do grupo dos Fridos, expressou: "Fiquei fascinada quando conheci Frida, pois ela tinha o dom de cativar a gente. Era única. Dispunha de enormes reservas de alegria, humor e paixão pela vida"5 (ZAVALA, 2005, p. 29, tradução do autor). Assim era Frida, uma mulher jovial, alegre e de personalidade impactante, que marcou sobremaneira o quarteto que com ela viveu instigantes experiências artísticopedagógicas.

Detalhando a experiência de (vi)ver a chegada de Frida na Escola La Esmeralda, o Frido Guillermo Monroy narra com detalhes e de maneira poética o encontro da professora com seus alunos:

Ela apareceu ali, de repente, como um magnífico ramo de flores. Disse-nos: "Bom, crianças, vamos trabalhar. Dizem que serei sua professora, mas não sou. Somente quero ser sua amiga. Nunca fui professora de pintura, nem creio que serei algum dia, pois, sempre estou aprendendo. Claro que pintar é a coisa mais bacana que existe, mas pintar bem é muito difícil. Para isso é necessário aprender bem o ofício, ter sua própria disciplina e, sobretudo, ter amor, sentir um grande amor pela pintura. [...] De vez em quando me permitirei fazer-lhes algumas observações sobre seu trabalho, mas também lhes peço, como amigos que somos, que quando eu lhes mostrar o meu vocês façam o mesmo. Nunca tirarei o lápis de sua mão para corrigi-los; quero que saibam, queridas crianças, que não existe um só professor em todo a Terra que saiba ensinar arte. Isso é realmente impossível. Falaremos muito, isso sim, das diferentes técnicas que se empregam nas artes plásticas, da forma e do conteúdo na arte e de todas aquelas coisas que se relacionam intimamente com 0 nosso trabalho. [... $]^{\prime \prime}$. (ZAMORA, 2015, p. 85, tradução do autor).

\footnotetext{
${ }^{5}$ No original: "Quedé fascinada cuando conocí a Frida, pues tenía el don de cautivar la gente. Era única. Disponía de enormes reservas de alegría, humor y pasión por la vida."

6 No original: "Ella apareció ahí, de pronto, como un ramo de flores estupendo. Nos dijo: 'Bueno, chamacos, vamos a trabajar; yo seré dizque su maestra; no soy tal. Solamente quiero ser su amiga. Nunca he sido maestra de pintura, ni creo que lo seré jamás pues siempre estoy aprendiendo. Es cierto que pintar es lo más padre que hay, pero hacerlo bien es muy difícil. Es necesario para eso aprender muy bien el oficio, tener con uno mismo una disciplina dura y, sobre todo, tener amor, sentir un gran amor por la pintura. [...] De vez en cuando me permitiré hacerles algunas observaciones a su trabajo, pero también les pido, como cuates que ya somos, que cuando les muestre lo mío ustedes hagan lo mismo. Nunca les quitaré el lápiz de la mano para corregirlos; quiero que sepan, queridos chamacos, que no existe un solo maestro en toda la Tierra que sepa enseñar arte. Eso es verdaderamente imposible. Hablaremos mucho, eso sí, de las diferentes técnicas que se emplean en las artes plásticas, de la forma y el contenido en el arte y de todas aquellas cosas que se relacionan íntimamente con nuestro trabajo. [... $]^{\prime}$." O texto original de Guillermo Monroy "Homenaje de un pintor a Frida Kahlo a los 22 años de su muerte" foi publicado no Jornal Exélsior, página 08, Cidade do México, em 17 de julho de 1976.
} 
Os princípios, procedimentos e práticas que compunham o processo pedagógico de Frida Kahlo podem ser considerados não convencionais. Ela não buscava impor seus pontos de vista, conceitos ou os regimes ópticos da história das artes, muito embora não deixasse de reconhecer sua importância. Primava pelo desenvolvimento da autocrítica de seus alunos, da autoexpressão e do aperfeiçoamento, de acordo com o temperamento de cada um. Frida comentava os trabalhos criados por eles, era enfática, mas não grosseira. Elogiava e criticava com a clareza e simplicidade de quem emitia sua própria opinião com sinceridade, sem desfazer ou idolatrar. Ela não se considerava uma professora de arte no sentido catedrático do termo e também considerava que ensinar arte é uma tarefa quase inatingível, deixando pistas para pensarmos a arte não como um conteúdo ou produto que se transmite, mas, como ação que, sim, se pode fomentar, mediar, orientar.

Em entrevista concedida à escritora Hayden Herrera, Monroy conta que Frida Kahlo, ao analisar os trabalhos dos alunos, dizia coisas do tipo:

\begin{abstract}
'Acho que podia carregar mais na cor'; 'Isso poderia estar mais equilibrado aqui'; 'Esta parte não está tão boa. Eu faria dessa forma, mas eu sou eu, e você é você. É uma opinião e eu posso estar errada. Se for útil para você, aceite, se não for, deixa de lado. [...] A única ajuda que ela nos dava era nos estimular, nada mais [...]. Ela não falava nem meia palavra sobre como deveríamos pintar, nem coisa alguma sobre estilo, como fazia o Professor Diego. Ela não fingia explicar coisas retóricas. Era entusiasmada com a gente. Ela dizia: 'Nossa, como isto está bem pintado!' ou 'Esta parte está muito feia'. O que ela nos ensinou, fundamentalmente, foi amar as pessoas e um gosto pela arte popular. Ela dizia, por exemplo: 'Olhem só este Judas! Que maravilhoso! Vejam que proporções! Como Picasso gostaria de conseguir pintar alguma coisa com esta expressividade, com esta força'. (HERRERA, 2015, p. 401402).
\end{abstract}

Frida Kahlo exercia uma postura de estimular seus alunos a uma forma de autonomia criativa, entusiasmava-se com eles e não Ihes dizia como deveriam criar. Isso instigame a ver em seu processo pedagógico pistas para refletir com Foucault (2017) acerca da estética da existência e da pedagogia da autonomia proposta por Freire (2007). Pensar na autonomia criativa do aluno não como um produto ou resultado a ser alcançado, mas como um processo de busca.

[...] passagem da heteronomia para a autonomia. Ou seja, a libertação advém de um trânsito no qual o sujeito ultrapassa

Revista Digital do LAV - Santa Maria - vol. 11, n. 1, p. 54-82- jan./abr. 2018 ISSN 1983 - 7348 http://dx.doi.org/10.5902/1983734831479 
a fase em que segue as regras sociais pela dependência dos outros e ainda espera o reconhecimento dos demais, entendidos como autoridades, como pessoas importantes a seus olhos [...]. (CASTELO BRANCO, 2010, p. 24).

Pensando por esse viés da autonomia criativa, a professora e o professor deixam de ser os legisladores do saber ao instaurarem relações dialógicas nas quais a autonomia do aluno não é um troféu a ser conquistado e nem um conteúdo a ser decorado. A autonomia como um trabalho constante de si, "uma qualidade de percepção de si no/com o mundo que, uma vez experienciada, acompanha, em estado de latência, o aluno por toda a vida", conforme argumenta Rocha (2012, p. 46). Estimulados em sua autonomia criativa, questionados sobre seus desejos e sentimentos sobre o que criar, motivados a amar as pessoas, a cultura e a história de seu povo, os alunos podem ultrapassar o mero seguimento de regras e métodos formais, percebendo 0 fluxo contínuo arte e vida.

Na prática docente de Frida Kahlo com seus alunos, diferentes ações e processos vão elencando aspectos preponderantes para uma compreensão das relações de ensinaraprender onde ambos aprendem, professor e aluno. A professora e o professor são importantes aos olhos dos alunos não como autoridades, mas como sujeitos estimuladores que provocam à invenção. A pouco conhecida trajetória docente de Kahlo traz importantes contribuições para provocar a reflexividade em torno do ensino das artes. O tipo de relação pedagógica e afetiva estabelecida com seus alunos, enfatizando sua autonomia inventiva, possibilita ampliar as visões acerca dessa criadora e professora, indo além dos discursos corriqueiros sobre sua biografia.

\section{As práticas do ver como estímulo para a criação}

Outra marcante característica dos processos pedagógicos de Kahlo é a observação da vida, das pessoas e dos acontecimentos para criar. Em uma carta escrita para sua mãe, Dona Matilde, em novembro de 1931, quando estava em Nova Iorque, Frida Kahlo expressou: "Eu não pintei nada ainda porque, primeiro, quero ver as coisas, mas vou começar a fazer algo"7 (JAIMES, 2016, p. 165, tradução do autor). Com essa noção de ver as coisas, o mundo, os acontecimentos, a vida, para, a partir daí criar, Kahlo estruturou seus processos criativos e pedagógicos. Nesse sentido foi que, nos processos criativos com seus alunos surgiram imagens de personagens adormecidos e bêbados das vias públicas, dos modelos da própria escola, da visão

\footnotetext{
${ }^{7}$ No original: "Yo no he pintado pues quiero ver primero las cosas, pero voy a empezar a hacer algo $[\ldots]$ ".
}

Revista Digital do LAV - Santa Maria - vol. 11, n. 1, p. 54-82 - jan./abr. 2018 ISSN 1983 - 7348 http://dx.doi.org/10.5902/1983734831479 
urbana que dáf os jovens pintores tinham acesso, autorretratos, retratos de familiares e personalidades que admiravam.

Em um relato sobre os incentivos dados pela professora Frida, Monroy expressa:

[...] certo dia a professora nos propôs ir para a rua, conhecer a vida para entendê-la melhor e poder pinta-la, assim, nos lançamos com grande entusiasmo, às vezes com ela e outras vezes sozinhos. Fomos a mercados, à fábricas, ao campo, nos misturamos com o povo e convivemos com ele. Participamos ativamente nas manifestações públicas de combate políticosocial. Ela nos disse que o contato direto com a vida e a intervenção nela, não como simples espectadores, mas como cidadãos socialmente ativos, nos abriria novos horizontes plásticos e enriqueceria muito nossa sensibilidade estética e humana. E assim foi. ${ }^{8}$ (ZAMORA, 2015, p. 87, tradução do autor).

Frida Kahlo costumava romper com os limites das paredes e muros da escola. Levava os alunos para a rua, mercados, periferias, igrejas e construções coloniais, para cidades vizinhas como Puebla e para as pirâmides de Teotihuacán. Visitavam artistas em seus locais de trabalho como os muralistas que na época estavam pintando a pleno vapor e até o artista mexicano Francisco Goitia (1882-1960) que, nesta época, vivia recluso em uma choça primitiva, pintando e ensinando as crianças na região de Xochimilco. Com isso ampliavam sua cultura visual, seus modos de ver, sentir, pensar e se expressar em suas criações.

Kahlo iniciou sua experiência como docente, com um grande grupo de estudantes, na localização original da Escola La Esmeralda, Beco La Esmeralda, Bairro de Guerrero, na região central da Cidade do México. Porém, as demandas de suas condições de saúde fizeram-na retornar ao confinamento do qual ela tentou escapar. Todavia, a convivência com os jovens proporcionou-Ihe tamanha alegria que não quis desistir e assim propôs aos estudantes e à direção da Escola La Esmeralda para seguir dando suas aulas em sua casa, em Coyoacán, evitando assim o transtorno do deslocamento diário até o centro.

\footnotetext{
${ }^{8}$ No original: [...] un día la maestra nos propuso ir a la calle, a conocer la vida para entenderla mejor y poder pintarla, así que nos lanzamos de veras con gran entusiasmo, a veces con ella y otras solos. Fuimos a los mercados, a las fábricas, al campo, nos mezclamos con la gente y convivimos con ella; participamos muy activamente en las manifestaciones públicas de combate político-social. Ella nos dijo que el contacto directo con la vida y la intervención en ella, no como simples espectadores sino como ciudadanos socialmente activos, nos abriría nuevos horizontes plásticos y enriquecería mucho nuestra sensibilidad estética y humana. Así fue."
}

Revista Digital do LAV - Santa Maria - vol. 11, n. 1, p. 54-82- jan./abr. 2018 ISSN 1983 - 7348 http://dx.doi.org/10.5902/1983734831479 
Com permissão da direção da escola e o consentimento da turma de quase vinte estudantes, Kahlo continuou desenvolvendo seus processos pedagógicos em sua residência. As aulas passaram a ser no jardim da Casa Azul, tornando esse contratempo um modo de ensino e aprendizagem artística ao ar livre. Frida Kahlo, a mulher que sabia tão bem fazer "das tripas coração", que transformava experiências dolorosas em arte, fez, outra vez, da limitação uma possibilidade de conexão arte e vida para além dos muros institucionais. Como a distância do centro até Coyoacán não era pequena, o grupo de alunos foi reduzindo o número para quatro, três rapazes e uma moça, sem dúvida os mais entusiasmados com os modos de Frida Kahlo ensinar. Eram eles, Fanny Rabel, Arturo García Bustos, Guillermo Monroy e Arturo Estrada, o fraterno grupo dos Fridos.

Arturo García Bustos descreveu a Casa Azul como um

ambiente caseiro, como um abismo de alegria e de estímulo para o trabalho, [...] um mundo cheio de pessoas trabalhando, enquanto eles compartilhavam o espaço do jardim com todos os animais que Frida cuidava com esmero: macacos, um veado, 'Granizo', uma águia, periquitos e dois cachorros Izcuintle, o 'senhor Xólotl' e a 'senhora Xolotzin', mais uma jaula cheia de pássaros. [...] os filhos dos serventes, pintores, um carpinteiro, químicos, artistas e até os membros do Partido Comunista. ${ }^{9}$ (KAHLO, Isolda, 2004, p. 156, tradução do autor).

Para os Fridos, a Casa Azul da professora Frida era um instigante espaço artístico e pedagógico. Os modelos a serem pintados consistiam em tudo o que ocupava e coloria aquele cenário: aves, macacos, cachorros, plantas, flores, frutas, esculturas pré-hispânicas, louças, peças artesanais, etc. Segundo Herrera (2015, p. 405), Frida buscava dar "um enfoque estético da vida cotidiana" nos processos criativos desenvolvidos com seus alunos. Entre seus procedimentos pedagógicos, ela expunha e rearranjava peças, objetos, alimentos e vegetais que serviam para os alunos pensar e inventar diferentes formas de composição. No jardim, no estúdio de Frida ou em diferentes espaços urbanos, as aulas eram levadas a sério, comenta Tibol (2005, p. 211 , tradução do autor), mas bem informais, e "se alguma disciplina fosse necessária nesse ambiente, era uma disciplina interior, autodeterminada"10.

\footnotetext{
${ }^{9}$ No original: "[...] ambiente hogareño como un abismo de alegría y de estímulo para el trabajo, [...] un mundo lleno de personas trabajando, mientras ellos compartieron el espacio del jardín con todos los animales que con esmero cuidaba Frida: monos, un cervato 'Granizo', un águila, pericos y dos perros Izcuintle, el 'señor Xólotl' y la 'señora Xolotzin', mas una jaula llena de pájaros. [...] los hijos de los sirvientes, pintores, un carpintero, químicos, artistas y los miembros del Partido Comunista."

10 No original: "Si alguna disciplina cabía en ese medio era una disciplina interior, autodeterminada."
} 
Na Casa Azul, onde a pintora recebia os Fridos pela manhã, esses novatos artistas puderam observar um longo desfile de personalidades das artes, da política e da cultura da época que iam visitar Frida. Juárez (2005, p. 11, tradução do autor) destaca que os Fridos "se instruíram nos pincéis sob a tutela de uma das figuras mais influentes do século XX mexicano"11. Entrar nesse ambiente íntimo da criadora, que era a sua casa, conhecer suas cores, seus recintos impregnados de odores, seus movimentos cotidianos, seus hábitos, foi um estímulo a mais para desenvolver seus projetos artísticos, sob uma tutela flexível, perspicaz e instigante. Recordando disso, Monroy relata:

E então, como Frida nos ensinou a pintar, comendo em seu refeitório? Ela dizia: 'notem, esse jarro, que bonita decoração ele tem. Notem a textura, por exemplo. O jarro é diferente do copo...'. Tudo isso, comendo... 'São diferentes texturas. E na fruta', nos dizia, 'aparece pele, como por exemplo, nas maçãs'. Estas conversas, para nós, eram muito interessantes, porque ela estava nos ensinando a ver, a sentir e apreciar as coisas e a sensibilizar-nos para com as coisas mais simples que havia. 'Meninos', ela nos chamava de meninos, 'vamos sair para a rua, ver a vida de perto para poder pinta-la melhor'. (FRIDA MAESTRA, 2004, tradução do autor).

Frida Kahlo considerava a relação arte e vida como um princípio orientador de seus processos criativos e pedagógicos. Aliado a isso, Herrera (2015) comenta que ela estimulava seus alunos a ler e aprender sobre história da arte, tanto nos livros e manuais de arte como desenhando esculturas e objetos pré-hispânicos nos museus de antropologia, arte colonial e outros espaços. Instigava-os a conhecer e se inspirar no que ela chamava de raízes da arte moderna, compartilhando com eles suas preferências artísticas que ia desde pintores anônimos de retábulos até aqueles mais conhecidos como, por exemplo, José María Estrada, Hermenegildo Bustos, José María Velasco, Julio Ruelas, Saturnino Herrán, Goitia, Posada, Dr. Atl e Diego Rivera.

Kahlo instigava as práticas do ver em seus alunos com as mais variadas formas de imagens, seja as imagens do dia a dia, das coisas que acontecem, imagens da arte, com seus livros que continham reproduções de obras, e imagens da biologia, utilizando atlas e microscópios, possibilitando-lhes o contato com imagens de plantas, animais, micro-organismos, anatomia, figura humana, educação sexual, arte erótica e reprodução humana. Assim, a criadora e professora Frida Kahlo

\footnotetext{
${ }^{11}$ No original: "[...] se instruyeron en los pinceles bajo la tutela de una de las figuras más influyentes del siglo XX mexicano."
}

Revista Digital do LAV - Santa Maria - vol. 11, n. 1, p. 54-82- jan./abr. 2018 ISSN 1983 - 7348 http://dx.doi.org/10.5902/1983734831479 
compartilhava seu fascínio pela vida, gerando com seus aprendizes saberes artísticos intimamente ligados com as experiências, o contexto, a relação corpo - ambiente.

Enquanto alguns professores tinham um pouco mais de pressa para que os estudantes aprimorassem rapidamente suas habilidades de pintura, Kahlo estimulava seus alunos a descobrir seu próprio ritmo e percurso de criação. Tibol (1993, p. 184, tradução do autor) comenta que, periodicamente, entre seus procedimentos metodológicos, ela realizava com seus alunos momentos de crítica coletiva, no intuito de "desenvolver, primeiramente, o sentido de autocrítica, ao qual se somava um sentido de solidariedade com as classes empobrecidas, fortalecido com os fundamentos do marxismo"12. O compromisso social do artista era um princípio imprescindível. Artistas lutadores e vanguardistas, empenhados em fazer do seu trabalho uma ferramenta de transformação sociocultural.

Frida Kahlo aprendeu da diversidade artística e política revolucionária própria do grupo e movimento artístico chamado Escola Mexicana. Conheceu e conviveu com destacados criadores mexicanos e vinculou-se a grupos de jovens que contribuíram com suas convicções e sua formação política e sociocultural. Esse entusiasmo com as causas sociais, que já pulsava em seu coração desde seus tempos de estudante, foi traduzido em forma de ensinamentos para com seus alunos. O processo pedagógico de Frida Kahlo com seus alunos, como destaca Reyes (2005, p. 22, tradução do autor) constituía-se de uma "fusão de arte, política e de um acúmulo de aprendizados que conformaram um estilo em cada um dos alunos"13. Em seu processo pedagógico, Kahlo se valia do diálogo e do estímulo aos alunos em suas criações, construindo um espaço onde a autonomia estava presente como um movimento a impelir diferentes fazeres.

Esse posicionamento na arte e na vida sociocultural dos fazeres pedagógicos de Frida Kahlo e seus alunos possibilita interpretar essas experiências a partir da relação entre a estética da existência e a luta social contra as variadas formas de fascismos e assujeitamento, conforme a perspectiva foucaultiana. Com Castelo Branco (2010, p. $35)$, compreendo "um modo de vida incansavelmente criativo, onde nos fazemos e nos desfazemos sempre que algo nos impulsione, a partir de um cuidado de si" que também é um descuidado de si, pois consiste em uma "posição política em parte

\footnotetext{
12 No original: "[...] to develop, earlier than others did, a sense of self-criticism, which should have harmoniously been joined by the fundamentals of Marxism."

13 No original: "[...] fusión del arte, la política y de un cúmulo de aprendizajes que conformaran un estilo en cada uno de los alumnos."
} 
pessoal, em parte coletiva". Esse processo de cuidado de si consiste também em desindividualizar-se, pois ancorado está na compreensão de que as modificações do mundo, as transformações sociais, não teriam lugar sem os processos de transformação das subjetividades.

Embora as motivações revolucionárias da arte mexicana daquele período fossem marxistas, e não foucaultianas, articulo, nessa bricolagem artístico-investigativa, diferentes modos de olhar os fazeres de Frida Kahlo e refletir com eles sobre arte e política. Sobre como a arte - ação do artista cidadão na sociedade - em sua ontologia política, pode ser coletiva-individual, como tão bem Diego Rivera (2007) caracterizou a arte de Kahlo. Os modos como essa criadora trama questões subjetivas e sociais em seus processos criativos e pedagógicos configuram potentes ações que podem ser olhadas de diferentes perspectivas teóricas. Pois, ao acentuar as relações do sujeito com o mundo, artista e sociedade, arte e política, diferentes visões que também abordem essas questões são bem-vindas justamente para ampliar as possibilidades de compreensão. O comprometimento sociocultural do artista é ímpeto que o impede de fixar-se na bolha da genialidade e do formalismo das belas-artes, é cuidado de si, dos seus, do seu contexto, que impele a intensificar o contato com a vida para recriá-la.

\section{Em Frida Kahlo, cores de uma autonomia criativa}

Simplicidade, sensibilidade e uma atitude de incompletude são características de Frida Kahlo repetidamente citadas por aqueles que conviveram com ela, tanto como criadora quanto como professora. Aportando importantes elementos na compreensão das práticas docentes exercidas por Frida, Fanny Rabel, em entrevista a Hayden Herrera, comenta que

o grande ensinamento de Frida era [...] abrir nossos olhos para ver o mundo, ver o México. Ela não nos influenciou por meio de sua pintura, mas por meio do seu jeito de viver, de olhar para o mundo, as pessoas e a arte. [...] Ela não impunha nada. Frida dizia: "Pintem o que vocês veem, o que vocês quiserem". Cada um de nós pintava de um jeito diferente, seguia o próprio caminho. Não pintávamos como ela. Havia muito bate-papo, piadas, alegria, sociabilidade. (HERRERA, 2015, p. 402).

"Pintem o que vocês veem", uma proposição artística e pedagógica que ascende a premissa de buscar a vida para fazer arte, ou melhor, para compreender que a arte não existe fora da vida da cultura - esse amplo e complexo cenário onde coexistem

Revista Digital do LAV - Santa Maria - vol. 11, n. 1, p. 54-82- jan./abr. 2018 ISSN 1983 - 7348 http://dx.doi.org/10.5902/1983734831479 
tantas formas de imagens. Refletir sobre Frida Kahlo sob a ótica da cultura visual um campo de estudos que compreende a arte entre tantas outras imagens e artefatos estéticos - possibilita pensarmos sobre as práticas do ver e se mover na contemporaneidade e como o ensino das artes pode incidir nesse cenário das relações entre corpos e imagens.

Revendo como o ensino tradicional das artes tem, por vezes, tolhido, em vez de aguçar e expandir os modos de ver e se mover dos corpos, impondo-Ihes, por vezes, regimes escópicos, movimentos, textos, partituras e imagens, é possível fazer um paralelo com os modos como as imagens técnicas, midiáticas, mercadológicas vêm performando nossas formas de ver, pensar e agir. Propor aos estudantes 'pintem, dancem, atuem, narrem - criem a partir do que vocês veem, sentem, pensam, vivem' pode ser um modo de aguçar a percepção desses corpos para com o que se passa em seu entorno. Articulando, assim, princípios e procedimentos pedagógicos que consideram a experiência, a afetividade, a relação corpo - ambiente e toda a trama corpomental de usar, pensar e dar a ver imagens.

É possível construirmos uma pedagogia sensível e do sensível, capaz de reconhecer os sujeitos do ensinar-aprender como corpos capazes, usando a cultura visual como matéria e oportunidade para impulsionar o seu "empoderamento criativo", conforme propõe Aguirre (2011, p. 92). Nessa perspectiva da educação a cultura visual, articulam-se estratégias de ruptura com os regimes sensíveis impostos pela política estética da modernidade, entendendo a cultura visual como espaço de interpelação e reflexividade, de contrastes, friç̧ões e críticas de diferentes formas de imagens artísticas, midiáticas, publicitárias, etc. Seguindo com Aguirre (2011, p. 93), são caminhos criativos e pedagógicos que consideram a cultura visual enredada com a experiência vital do sujeito, ou seja, "a cultura visual como experiência" que - ao enredar as relações corpo e imagem - pode mover imaginários coletivos e subjetivos, processos criativos e novos regimes de identificação do estético.

No que tange a influência de Frida Kahlo sobre seus alunos, é possível perceber que ela não os influenciou a serem seguidores de seus procedimentos artísticos, de seus temas, de seu estilo de criar. Nos modos de Kahlo ensinar, percebo a dialogicidade, a descontinuidade e o descondicionamento do corpo como fatores determinantes. Vejo a atitude da professora e do "professor que não se perpetua no aluno", pois o "pacto em sala de aula" busca "reconhecer a diferença, a descontinuidade, o intervalo, o desengate, o entre" como princípios e gestos inerentes às trocas que aí

Revista Digital do LAV - Santa Maria - vol. 11, n. 1, p. 54-82 - jan./abr. 2018 ISSN 1983 - 7348 http://dx.doi.org/10.5902/1983734831479 
se dão, conforme reflete Rocha (2012, p. 40). Trata-se de uma relação ensinaraprender não pautada na transmissão, mas no diálogo, na processualidade e na partilha, cara ao ensino das artes. Uma educação que prima pela desconstrução de respostas sensório-motoras já programadas, pelo descondicionamento do corpo em relação aos modos automatizados de aprender, por modos autônomos de (se) (mo)ver.

Kahlo preocupava-se em fazer de seus alunos artistas seguros de si mesmos, de sua identidade e da história de seu povo. Nesse sentido, importava à professora proporcionar-Ihes experiências com as quais pudessem ampliar sua cultura visual, fazendo com que percebessem as imagens que os rodeavam, a arte a cultura popular, os murais e as questões socioculturais aí implicadas. Zamora (2015) comenta que, conforme relatos dos Fridos, com Kahlo eles aprenderam mais sobre sua vida e seu entusiasmo pelas coisas do que propriamente sobre sua arte. Eles não aprenderam a pintar como ela pintava, não se tornaram discípulos a difundir uma técnica ou método Frida Kahlo, mas, sim, aprenderam do seu amor à arte, à cultura popular, às causas sociais, ao México.

Frida Kahlo não se considerava uma artista plena, muito menos uma grande professora de arte. Sua postura de inacabamento e de abertura ao aprendizado eram constantes e transpareciam em seus modos de ensinar. De acordo com Zamora (2015), ela não foi o tipo de professora que carrega grandes volumes de conhecimentos os quais não consegue transmitir, mas uma mediadora que, compartilhando informações fundamentais com seus alunos, teve a capacidade de impeli-los a descobrir, por seus próprios meios, aquilo que julgava que lhes seria útil em seu desenvolvimento como criadores. Nessas relações pedagógicas voltadas às experiências articula-se a liberdade de expressão, a construção de caminhos próprios, a autonomia criadora, a autodidaxia, o empoderamento criativo dos corpos.

Com Franco (2007, p. 168, tradução do autor) percebo que, em sua prática docente, Frida Kahlo exerceu uma "respeitosa liberdade criativa"14 com seus alunos, aos quais se dirigia para mediar e instigar processos de criação sem impor preceitos em sua execução. Relatos dos seus alunos mais próximos, os Fridos, denotam a postura sincera, bem-humorada, brincalhona e alegre com que ela se dirigia a eles, instaurando processos pedagógico-criativos em que a afetividade permeava 0

\footnotetext{
${ }^{14}$ No original: "respetosa libertad creativa".

Revista Digital do LAV - Santa Maria - vol. 11, n. 1, p. 54-82- jan./abr. 2018 ISSN 1983 - 7348 http://dx.doi.org/10.5902/1983734831479
} 
ensinar-aprender. Sem impor critérios ou tendências, Kahlo primava pela formação autodidata, a exemplo de como ela própria se tornou uma criadora. Uma postura político-pedagógica que vê a autodidaxia, a autoexpressão e a imbricação das práticas do ver com o fazer artístico, como modos para construir uma identidade artística não engessada em métodos rígidos que reduzem a espontaneidade.

Ressalto que não necessariamente a autodidaxia é uma afronta ao ensino formal e à formação artística. Compreendo autodidaxia não como falta de formação, mas como uma didática pessoal autônoma que usa, recria, refuncionaliza e se apropria daquilo que aprende com perspicácia, sejam esses aprendizados provenientes do ensino formal, das pedagogias culturais ou da vida, como se costuma dizer. Autodidaxia como atitude de gerir o próprio aprendizado, autonomia didática, liberdade formativa e criativa que, em processos educacionais alicerçados na autonomia e na dialogicidade, não sustenta binômios como dominador $x$ dominados, sábio $x$ ignorante, mas compreende professores e estudantes como parceiros na construção e partilha de conhecimentos.

\section{Uma potente experiência criativa e sócio-política}

Mesmo após o curto período em que exerceu formalmente o cargo de professora da Escola La Esmeralda, Frida Kahlo continuou desenvolvendo ações criativas e pedagógicas e orientando trabalhos artísticos dos Fridos. Entre as instigantes experiências que com eles realizou, entrecruzando arte, cultura popular e intervenção social, estão as duas versões da pintura dos murais nas paredes externas da Pulqueria La Rosita - uma espécie de bar popular especializado em servir uma típica bebida mexicana chamada pulque -, em 1943 e 1952; a pintura do polêmico painel Quienes nos explotan? Y como nos explotan? para a Exposición de Arte Libre 20 de Noviembre, em 1945; a controversa pintura dos murais no salão de festas de casamento do Hotel Posada del Sol, em 1949; e a pintura dos murais nas paredes da Casa da Mãe Solteira Josefa Ortiz Domínguez, uma estimulante experiência criativa e pedagógica que evidencia as preocupações sociais, políticas e de gênero que perpassavam as práticas pedagógicas de Frida Kahlo. E com esta experiência, dou prosseguimento a esta reflexão.

Em 1945, Frida Kahlo e os Fridos realizaram a pintura de murais na Casa da Mãe Solteira Josefa Ortiz Domínguez. Hoje essa instituição é um centro cultural e de assistência social denominado Centro de Desenvolvimento Comunitário Ana Maria Hernández e Foro Cultural Ana Maria Hernandez, localizado na Colônia La Concepción,

Revista Digital do LAV - Santa Maria - vol. 11, n. 1, p. 54-82 - jan./abr. 2018 ISSN 1983 - 7348 http://dx.doi.org/10.5902/1983734831479 
Delegação de Coyoacán, México, próximo à Praça de La Conchita e ao lado do belo Parque Frida Kahlo. O Frido Arturo Gracía Bustos comenta que

A Casa da Mãe Solteira era uma casa onde haviam umas lavanderias públicas de Coyoacán nas quais as mulheres associadas e as lavadeiras pagavam cinco centavos, como sua contribuição, para ter direito ao uso de água, ferro de passar roupa, ingressando aí por serem mães solteiras. (FRIDA MAESTRA, 2004, tradução do autor).

Tanto quanto os processos criativos na Pulqueria La Rosita, esse, nas paredes dessa lavanderia pública despertou o entusiasmo dos Fridos que demonstravam aderir aos valores estéticos e socioculturais apresentados pela professora Frida Kahlo. Ao vincular o interesse sociocultural dos Fridos, as imagens e vivências das lavadeiras e mães solteiras, o processo criativo da lavanderia manifesta uma significativa trama de afetos, experiências, questões políticas e de gênero. Na época, essa cooperativa de mulheres era liderada por Ana Maria Hernández, uma comprometida líder social que mais tarde legou o nome à cooperativa. Dona Ana Maria acolheu a proposta de Frida Kahlo e dos Fridos que decidiram pintar as paredes do salão de atos da sede da cooperativa de lavadeiras.

"A temática deste mural foi o trabalho, a unidade, a fraternidade, a libertação da mulher e as condições de vida das lavadeiras"15, precisa Monroy (2012, p. 263, tradução do autor), dando a ver a estimulante vinculação vida e arte articulada nesse processo de criação. Os relatos dos Fridos denotam elementos da potência e do impacto desse processo criativo em suas vidas e nos trabalhos que desenvolveram enquanto artistas e cidadãos. Bustos destaca:

Fizemos os projetos e viemos mostrar às lavadeiras e elas é que decidiram o que devíamos pintar. [...] A mim tocou pintar as lavadeiras já em um mundo mais industrializado, as mulheres portando bandeiras, as crianças já atendidas nas creches e a esperança do mundo com que sonhavam. (FRIDA MAESTRA, 2004, tradução do autor).

O processo criativo contou com a participação das mulheres da lavanderia que opinaram acerca dos esboços criados pelos Fridos. "Os murais pintados foram selecionados pelas próprias mães que elegeram meu projeto para a parede central e

\footnotetext{
${ }^{15}$ No original: "La temática de este mural fue el trabajo, la unidad, la fraternidad, la liberación de la mujer y las condiciones de vida de las lavanderas."
} 
que foi o de maior proporção"16 (MONROY, 2012, p. 263, tradução do autor). Na perspectiva de animar as mulheres em sua condição de opressão e de enaltecê-las enquanto protagonistas de sua atuação sociocultural, os Fridos as convocaram e em plenária elas os auxiliaram na escolha das imagens a serem pintadas. Nas imagens projetadas por Bustos, o contexto da industrialização e a luta popular das mulheres na construção de um mundo mais justo para si e para seus filhos. Imagens geradoras de identificação e esperança para a transformação do cotidiano sofrido de negação de seus direitos sociais. Com entusiasmo semelhante ao de Bustos, Estrada expressa:

\begin{abstract}
Pintamos a vida das lavadeiras. [...] Havia uma creche. E nessa creche davam de comer às crianças. [...] Na mesma ala onde elas, também, costuravam, às vezes vinha uma professora ensinar as primeiras palavras às crianças. E eu a pintei apontando uma imagem da sociedade em que essas crianças iam viver, onde haviam diferenças sociais, e aqui ela está apontando para um rico. (FRIDA MAESTRA, 2004, tradução do autor).
\end{abstract}

Pintar a vida, o grande princípio ensinado e compartilhado pela professora Frida Kahlo, tornou-se um guia para os fazeres artísticos dos Fridos. É possível pensar sobre as possíveis e diferentes formas de identificação que os Fridos possibilitaram àquelas mulheres, ao se verem pintadas em murais nas paredes do local que as acolhia e onde trabalhavam em cooperativa. Isso evoca a compreensão das artes "como formas de inscrição do sentido da comunidade" e a maneira como "fazem política", de acordo com a inserção social dos artistas e como estes buscam refletir sobre as estruturas e movimentos sociais em seus processos criativos (RANCIÈRE, 2014, p. 18-19).

Ainda é possível ver essa experiência artística na perspectiva da "estética da política", bem como reflete Aguirre (2011) com base na perspectiva rancieriana. Percebo como se o processo de criação dos Fridos na lavanderia pública desencadeasse processos de criação de dissensos na partilha do sensível e outros olhares sobre a fusão arte e vida, conforme propõe Rancière (2014). Processos criativos como esses dão a ver quem pode tomar parte ou ter acesso às experiências estéticas, possibilitando que quem não tem imagens, as tenha; tornam visível o que não era, fazendo com que quem não pode estar em outro lugar que não o do trabalho, tenha acesso a esse lugar da imagem, da arte, dos símbolos.

\footnotetext{
${ }^{16}$ No original: "Los murales que se pintaron fueron seleccionados por las propias madres, quienes eligieron mi proyecto para la pared central, que fue lo de mayores proporciones."
} 
Nas paredes da lavanderia os murais podem ser vistos como imagens que geram espaços de encontro, confronto, de identificação e reconhecimento de que "aquilo que é visto atua como espelho do sujeito que vê" (AGUIRRE, 2013, p. 295). A imagem também vê o sujeito que a vê e este se confronta com seus próprios sentidos de ser aquilo que o vê a partir de onde o vê. Nesse sentido, é possível pensar que aquelas mulheres, ao se identificarem com e nas imagens criadas pelos Fridos, produziam sentidos de se ver nas imagens, de ser a imagem que viam e de que as próprias imagens as viam. Nessas relações, penso que os sujeitos podem nutrir sua autoestima, alentar suas esperanças em melhorar suas condições socioculturais e fazer prosperar sua vida, trabalho, realização.

Monroy relata que:

Encantou-Ihes o fato de que Estrada as pintou em suas máquinas de costura. [...] Eu as pintei e pus o General Cárdenas no meio delas fazendo coletas para reunir fundos para continuar a organização de sua casa. Mas um detalhe que as comoveu muito é quando elas aparecem chorando sobre os túmulos de seus esposos e ficam sozinhas com seus filhos. (FRIDA MAESTRA, 2004, tradução do autor).

O estabelecimento da lavanderia foi fruto da luta, reivindicação e trabalho comunitário do grupo de mulheres que, conforme Dubernard (2007) receberam auxílio do dono de uma fábrica de papel de Coyoacán e, conforme Monroy (2012), do General Lázaro Cárdenas. Em seu governo, o presidente Cárdenas havia custeado a construção e instalações de diversas casas para lavanderias públicas com espaços para lavar, passar e costurar roupas, creche e berçário, refeitório e salão de atos.

Foram pintadas imagens da creche, uma grande conquista da cooperativa de mulheres e motivo de orgulho para as trabalhadoras; imagens das aulas, da alfabetização e da boa alimentação que as crianças, filhos das trabalhadoras, lá recebiam; imagens do esforço árduo e do trabalho cotidiano nos tanques, no atelier de costura, no refeitório; imagens do sofrimento das mulheres abandonadas que precisavam trabalhar lavando roupas para manter suas casas e sustentar seus filhos; imagens das líderes da cooperativa e do General Lázaro Cárdenas; imagens da industrialização e do tecnicismo, e também de esperança, avanço, conquistas e libertação das mulheres trabalhadoras, incluindo a figura de Dona Josefa, símbolo e exemplo da luta libertária feminina.

Revista Digital do LAV - Santa Maria - vol. 11, n. 1, p. 54-82- jan./abr. 2018 ISSN 1983 - 7348 http://dx.doi.org/10.5902/1983734831479 
Arturo García Bustos (KAHLO, Isolda, 2004) comenta a importância de se destacar a promoção da arte e da cultura popular e também o cunho pedagógico levado a cabo por Frida Kahlo com essa experiência, uma iniciativa dela e da trabalhadora social Ana Maria Hernández. Ao levar seus alunos para realizar um processo criativo em um estabelecimento social que abrigava mulheres, intitulado de Casa da Mãe Solteira, percebe-se nuances dos princípios sociais, culturais e de gênero, vividos, compartilhados e ensinados pela professora Frida Kahlo. Como professora, ela provoca uma situação pedagógica interpeladora, onde seus alunos e as mulheres da Casa da Mãe Solteira relatam suas histórias, narrativas e afetos no decorrer do processo criativo. Em entrevista a Herrera, Bustos comenta:

Meu projeto em particular comoveu profundamente aquelas mulheres. Elas choraram quando o viram, porque disseram que as fazia pensar nas desgraças da vida delas. Elas pediram que escondêssemos um pouco o sofrimento, pois algumas delas iam aparecer como retratos no mural. (HERRERA, 2015, p. 412).

Vejo nesse processo criativo e pedagógico de Frida Kahlo com seus alunos, envolvendo o grupo de mulheres da Casa da Mãe Solteira, o que Aguirre (2011, p. 89) chama de "pedagogia da sensibilização e do empoderamento". Uma experiência, um tempo e espaço de ensinar-aprender arte e com a arte, de partilha do sensível distante do treinamento dos hábitos, da percepção e do gosto das aristocracias que detém os códigos da fruição estética das artes. Um conjunto de experiências de identificação da arte e com a arte enquanto conjunto de imagens que pertencem a um universo comum e assim podem deflagrar espaços de emancipação, de crescimento pessoal e coletivo. De enriquecimento da sensibilidade, ampliação das possibilidades de prazer, de solidariedade social, construção de conhecimento, reconhecimento das paixões vitais e do sofrimento dos outros para não permitir que sejam subjugados.

Não se trata de conferir à arte uma característica messiânica, tampouco de veículo de propaganda política, terapia ou caridade. Em vez disso, conforme a perspectiva da cultura visual e a consideração da experiência nos processos de criação, promover espaços em que se experimente e investigue "a negociação entre esse aspecto emotivamente impactante da arte e a presença da estética nos objetos de cada dia" (AGUIRRE, 2011, p. 88). Penso que essas vinculações arte e vida, imagens e contexto - corpo-experiência-imagem - nos processos criativos e pedagógicos, a exemplo da 
prática docente de Frida Kahlo, podem adensar o pensamento crítico e o empoderamento criativo.

Analisando a importância dessa interpeladora experiência criativa, Comisarenco (2015) destaca as reveladoras intensões de Frida Kahlo e seu grupo de alunos:

\begin{abstract}
A temática dos murais corrobora a consciência de gênero que caracterizou o trabalho de Frida e que imprimiu, pelo menos neste caso, uma orientação particular à expressão de seus alunos para que prestassem atenção a uma problemática social eminentemente feminina. Ao mesmo tempo, os artistas buscaram dignificar a vida destas lavadeiras com seus retratos nos murais. [...] que significavam uma rota alternativa para o muralismo: o compromisso social com uma instância coletiva, uma organização popular mais de acordo com as intenções propostas pelo primeiro muralismo do que as oferecidas pelas instituições governamentais e privadas que atraiam a outros muralistas naquele momento. ${ }^{17}$ (COMISARENCO, 2015, p. 170-172, tradução do autor).
\end{abstract}

Bustos destaca que esta vivência "foi muito interessante, uma experiência coletiva muito especial na qual se notou o interesse social de [...] Frida Kahlo"18 (KAHLO, Isolda., 2004, p. 154, tradução do autor). Notam-se também as estratégias pedagógicas com que Kahlo enlaça arte, política, cotidiano e aprendizado. Desse modo, instruindo seus alunos em uma forma não convencional de muralismo, distinta das propostas do muralismo oficial. Trata-se de uma forma de produção cultural alternativa que, ao imbricar criação, pedagogia e estética da existência, instaura uma forma de arte transpassada por uma política, pessoal e coletiva, e traz para o primeiro plano, imagens de sujeitos, experiências e espaços marginalizados pelos sistemas artísticos e socioculturais tradicionais.

A inauguração dos murais foi em 08 de março de 1945, no dia internacional da mulher. Segundo Monroy (2012), como na ocasião da Pulqueria La Rosita, o trabalho artístico nas paredes da Casa da Mãe Solteira também foi inaugurado com uma estrondosa festa popular. O convite da inauguração ressaltava o caráter benevolente,

\footnotetext{
17 No original: "La temática de los murales corrobora la conciencia de género que caracterizó el trabajo de Frida y que imprimió, por lo menos en este caso, una orientación particular a la expresión de sus alumnos que prestaron atención a una problemática social eminentemente femenina. Al mismo tiempo, los artistas buscaron dignificar las vidas de estas lavanderas con sus retratos en los muros. [...] porque significaban una ruta alternativa para el muralismo: el compromiso social con una instancia colectiva, una organización popular más acorde con las intenciones propuestas por el primer muralismo que las ofrecidas por las instituciones gubernamentales y privadas que atraían en aquel entonces a otros muralistas."

18 No original: "Fue muy interesante, una muy especial experiencia colectiva en la que se notó el interés social de [...] Frida Kahlo."
} 
social e político do trabalho artístico feito em benefício do povo. Professores e alunos da Escola La Esmeralda, representantes da população local de Coyoacán e as lavadeiras estavam presentes junto de Frida Kahlo, Diego Rivera e os Fridos que estavam radiantes com a finalização de mais essa experiência. Em entrevista a Herrera (2015, p. 413) Fanny Rabel comenta que houve "discursos e foi mais um evento político do que uma festa. [...] música, folhetos impressos com um corrido e pratos de tacos recheados de cacto de nopal, preparados pelas lavadeiras".

Os murais pintados nas paredes da Casa da Mãe Solteira Josefa Ortiz Domínguez permaneceram visíveis até os anos setenta. Com as mudanças e reformas, nos processos de reutilização desses espaços, os murais se perderam, permanecendo apenas documentos do processo criativo, como os esboços das pinturas e as fotografias feitas aos cuidados de Frida Kahlo. Hoje, nesse espaço que sediou esta impactante experiência artística de Kahlo com seus alunos, funciona o Centro de Desenvolvimento Comunitário Ana Maria Hernández e também o Foro Cultural Ana Maria Hernández. Ao passo que o centro comunitário presta serviços de apoio nas áreas médica, odontológica, social e educativa e de capacitação profissional para mulheres em corte e costura, estética, funções administrativas e línguas, o foro cultural é um espaço artístico (teatro-auditório) que sedia espetáculos, palestras, exposições, congressos, cursos e oficinas de uma ampla gama de atividades culturais.

\section{Em Frida Kahlo, cores para uma (est)ética da docência}

O movimento criativo e pedagógico de Frida Kahlo, esse fluxo de imagens - artefatos, ideias, ações - que atravessa suas práticas artísticas e docentes têm me possibilitado articular uma compreensão de (est)ética da docência através de uma bricolagem reflexiva através das concepções da estética da existência de Michel Foucault e da boniteza e decência na docência de Paulo Freire. Ambos, cada qual de sua perspectiva teórica, pensam em uma ética-estética, uma postura de vida bela - justa, generosa, boa. Não me furto à liberdade reflexiva e à licenciosidade poética a que as táticas bricoladoras de investigação me impulsionam, para friccionar diferentes correntes de pensamento e articular uma visão particular através de diferentes concepções em torno de uma temática ou conceito.

Nas reflexões que discorreu em seu curso no Collège de France, em 1984, acerca do cinismo, desde a antiguidade grega à modernidade, Michel Foucault (2017, p. 141) buscou mostrar a seus alunos e a si próprio uma compreensão de "estética da

Revista Digital do LAV - Santa Maria - vol. 11, n. 1, p. 54-82 - jan./abr. 2018 ISSN 1983 - 7348 http://dx.doi.org/10.5902/1983734831479 
existência", ou seja, de como a existência (bíos) foi constituída, no pensamento grego, como um objeto estético, "como objeto de elaboração e de percepção estética: o bíos como uma obra bela". Foucault atenta para que a maneira de ser e de se conduzir do homem seja seu objeto de preocupação estética, objeto histórico, um trabalho contínuo, exigente e sempre renovado de dizer-a-verdade, amarrado ao cuidado de si, e, em consequência, dos outros. Trata-se do princípio da fala franca a ética - nas palavras, nas ações e nas coisas, e do princípio de ter de se aplicar a si mesmo, de cuidar de si.

Noutra de suas reflexões sobre a genealogia da ética, Foucault (1995) se pergunta por que diferentes coisas se tornam objetos artísticos e por que a vida humana não poderia se transformar em uma obra de arte. Outra vez em suas aulas, recorre ao contexto da arte moderna entendendo-a como outro possível veículo do cinismo enquanto postura radical de vida que expressa no corpo, nos gestos, no modo de vestir, na maneira de se conduzir e viver o dizer-a-verdade - assim como o vê nos cínicos da Grécia antiga, no cristianismo medieval e em movimentos revolucionários do século XIX. Para esse filósofo, na arte moderna da cultura europeia, o cinismo, pensado como princípio da estética da existência, se torna singularmente importante e o faz refletir sobre a vida de artista.

\begin{abstract}
É a ideia, moderna creio, de que a vida do artista deve, na forma mesma que ela assume, constituir um testemunho do que é a arte em sua verdade. Não somente a vida do artista deve ser suficientemente regular para que ele possa criar sua obra, mas sua vida deve ser, de certo modo, uma manifestação da própria arte em sua verdade. Esse tema da vida de artista [...] como condição da obra de arte, autenticação da obra de arte, obra de arte ela própria, é uma maneira de retomar, sob uma outra luz, sob um outro perfil, com uma outra forma, é claro, esse princípio cínico da vida como manifestação de ruptura escandalosa, pela qual a verdade vem à tona, se manifesta e toma corpo (FOUCAULT, 2017, p. 164).
\end{abstract}

Nessa perspectiva de radicalidade arte-vida, Foucault reflete a arte não como ornamentação e imitação do real, mas como desnudamento da experiência, desmascaramento, decapagem, escavação, irrupção, redução violenta ao elementar da existência. Essa compreensão, destaca o filósofo, não caracteriza toda a arte possível atualmente, mas a arte que se constitui como irrupção do que na cultura, normas sociais e cânones estéticos, não tem direito ou possibilidade de expressão, citando Baudelaire, Manet, Francis Bacon, entre outros, como exemplos desse antiplatonismo da arte moderna.

Revista Digital do LAV - Santa Maria - vol. 11, n. 1, p. 54-82- jan./abr. 2018 ISSN 1983 - 7348 http://dx.doi.org/10.5902/1983734831479 
Embora Foucault não tenha se referido à arte e vida de Frida Kahlo, me atrevo a pensar que, ao misturar as vestimentas autóctones de tehuana com outras peças, tecidos, acessórios e ornamentos, e também as vestimentas tipicamente masculinas, fazendo do vestir uma prática estética articulada com esmero e propósito; ao entrelaçar experiência, corpo e imagem em seu projeto artístico; ao fazer uso de imagens provindas de diferentes nichos culturais, populares, artísticos e técnicos em seus processos criativos; ao produzir entrelaçamentos políticos e estéticos em uma forma de arte individual-coletiva; na sua militância nas causas revolucionárias; e ao primar pela autodidaxia e pela autonomia criativa de seus alunos em suas práticas docentes, Frida Kahlo constitui uma complexa trama arte-vida que abre brechas para pensar na radicalidade corporal onde vida e obra se (co)fundem, (co)incidem.

A estética da existência pode ser compreendida como um modo de vida, qual seja, a "vida artista", que não é um estado destinado a determinados eleitos, ou, usando as palavras de Frida Kahlo, "conhecedores de arte que se presumem escolhidos de Deus, [...] cambada de estúpidos que se dizem civilizados, faladores, chamados de gente culta"19 (HERNÁNDEZ; TRUJILLO, 2007, p. 183, tradução do autor). A vida artista não quer dizer vida artística, mas um modo de vida realizável por todo sujeito capaz de questionamento ético e compreensão de que o prazer pode assumir forma cultural.

Para Foucault a vida artista [...] designa o trabalho que certas pessoas desenvolvem no sentido de tornar suas vidas belas, generosas, radiosas, intensas, numa relação com uma comunidade de iguais, todos voltados para o desenvolvimento de uma estética da existência, ocupados em fazer da própria vida, e da vida de seus próximos, uma obra de arte. (CASTELO BRANCO, 2010, p. 29).

A vida artista, enquanto recusa do assujeitamento e possibilidade de todo sujeito inventar-se, não é sinônimo de vida artística, biografia, produção ou itinerário criativo de um artista. É pelas características de questionamento a formas vigentes de poder, pela criação de si, pela radicalidade das experiências no corpo, gesto, vestimenta, por suas formas de vida intensas, na contramão de formas de vida e de arte dominantes, que não vejo e interpreto Frida Kahlo através dos arquétipos tradicionais do que é ser uma artista, mas pelas lentes da compreensão da vida (de) artista, da estética da existência. Seus vínculos com seu presente histórico, sua inconformidade,

\footnotetext{
${ }^{19}$ No original: "[...] conocedores de arte para presumir de escogidos de Dios, [...] manada de estúpidos dizque civilizados, habladores, llamados 'gente culta'."
} 
sua luta revolucionária com dimensões pessoal e social e seus ímpetos e estímulos para posturas autônomas, configuram um modo de vida que, em meio a todas as suas calamidades, foi incansavelmente criativo.

Esse modo de pensar a vida como obra de arte, uma vida ética como uma vida bela me leva a refletir sobre as práticas docentes de Frida Kahlo em relação à compreensão de decência e boniteza - ética e estética - da docência em Paulo Freire (2007). A ética em Freire baseia-se na noção de responsabilidade ética no mover-se no mundo, de que às palavras que falta corpo, exemplo, nada valem, ou seja, de que pensar é fazer. Nessa perspectiva, Freire propõe sua visão de ética e estética da docência, uma outra forma de pensar que, diferente, mas não necessariamente oposicionista à de Foucault, me possibilita ver Frida de outra perspectiva que lhe confere não apenas distintos sentidos, como estatutos ontológicos diversos. Conforme Kincheloe e Berry (2007), trata-se de um envolvimento criativo com as compreensões conceituais que não faz equivalências, mas inter-relações e fricções entre conhecimentos de distintos domínios para compreender as interconexões que moldam.

Para Paulo Freire (2007), a autêntica prática do educador democrático, criador, indagador, inquieto, curioso, humilde e persistente constitui uma experiência política, ideológica, pedagógica, estética e ética em que a boniteza está de mãos dadas com a decência, "ética ao lado sempre da estética. Decência e boniteza de mãos dadas" (p. 32). Modo de pensar ético e gerador de boniteza. Bonitezas de estar no mundo e com o mundo, intervir no mundo, conhecer o mundo. Freire (2007) argumenta que na relação com o mundo, na "invenção da existência" (p. 51), o corpo tem a possibilidade de ser criador de beleza e de feiura. Nossa capacidade de intervir no mundo - possibilidade de embelezar ou enfeiar o mundo - nos inscreve, a mulheres e homens, como seres éticos.

Sou professor a favor da boniteza de minha própria prática, boniteza que dela some se não cuido do saber que devo ensinar, se não brigo por esse saber, se não luto pelas condições materiais necessárias sem as quais meu corpo, descuidado, corre o risco de se amofinar e de já não ser o testemunho que deve ser de lutador pertinaz, que cansa mas não desiste. Boniteza que se esvai de minha prática se, cheio de mim mesmo, arrogante e desdenhoso dos alunos, não canso de me admirar (FREIRE, 2007, p. 103).

Nesse movimento de pensamento, Freire pensa as relações docência e discência "dodiscência" - onde ambos aprendem, professores e alunos. Relações de ensinar- 
aprender constituídas por posturas dialógicas, abertas, indagadoras. A boniteza da prática docente se acha na luta pelo respeito à autonomia e à identidade do educando, ajudando-o para que vá sendo o artífice de sua formação-aventura criadora onde a boniteza é sua afirmação como sujeito. Entre o que me motiva a olhar a prática docente de Frida Kahlo pelo viés da boniteza e decência na docência de Freire e da estética da existência de Foucault, nas possíveis interconexões que essas visões moldam, está a dimensão individual-coletiva, pessoal e política, com a qual percebo que ao trabalhar pela autonomia do aluno, o professor não o faz por complacência, caridade, pena, heroísmo, mas também para construir-se.

Nessa disponibilidade permanente à vida, entrega de corpo inteiro, pensar crítico, emoção, curiosidade, desejo, aprendemos a ser nós mesmos, na relação com o outro e também com aquilo que é contrário a nós. "E quanto mais me dou à experiência de lidar sem medo, sem preconceito, com as diferenças, tanto melhor me conheço e construo meu perfil" (FREIRE, 2007, p. 134). A abertura ao outro possui razão ética, fundamento político, referência pedagógica. A boniteza que há na experiência da abertura ao outro é a viabilidade do diálogo, experiência fundante do ser inacabado.

A (est)ética do movimento criativo e pedagógico de Frida Kahlo se fundamenta na radicalidade que vai da expressão pessoal dos fatos e sentimentos até o ósseo de sua verdade, das referências a ela mesma que, por sua exatidão e intensidade, chegam a uma extensão universal e a um papel social que Tibol (1977, p. 98, tradução do autor) ousa chamar "poeticamente didático e rigorosamente dialético". Com seus processos criativos e suas práticas docentes na Escola La Esmeralda e fora dela com os Fridos, Kahlo me possibilita refletir sobre uma (est)ética da docência que, à luz de Freire e Foucault, tem a ver com ensinar aprendendo, com estimular a autonomia criadora, a autocriação, com abrir-se ao outro e estimular o desenvolvimento de diferentes subjetividades, com a dialogicidade que faz palpitar aprendizados para além da transmissão pedagógica formal. A (est)ética da docência, a exemplo de Frida Kahlo, não busca integrar arte e vida, mas reconhecer que essa vinculação é inata e que o desafio está em incorporá-la no ensino das artes.

Em entrevista a Raquel Tibol, Diego Rivera, em 1953, destaca que não é a tragédia que protagoniza na arte de Frida, pois as trevas da dor são apenas um pano de fundo aveludado para a luz de "sua força biológica [...] e sua força invencível para viver e ensinar a seus camaradas, os humanos, como resistir às forças contrárias" para construir um mundo futuro no qual "o valor coletivo da vida em conjunto fará surgir

Revista Digital do LAV - Santa Maria - vol. 11, n. 1, p. 54-82 - jan./abr. 2018 ISSN 1983 - 7348 http://dx.doi.org/10.5902/1983734831479 
o verdadeiro período histórico e realmente humano de nossa sociedade" (TIBOL, 1977 , p. 12, tradução do autor). Corroboro essa compreensão do camarada Rivera percebendo aí as cores da (est)ética que aventa o movimento criativo e pedagógico de Frida Kahlo. Uma peculiar forma de estética da existência e de boniteza e decência na docência que, no corpo, nos gestos, no vestir, no criar e no ensinar-aprender manifesta a radicalidade da vida como obra de arte, da obra de arte como vida, da relação arte-vida.

"Quem diria que as manchas vivem e ajudam a viver? Tinta, sangue, odor. Não sei que tinta usar [...]" (KAHLO, 2017, p. 77, tradução do autor). Como Frida Kahlo, por vezes não sei que cores usar. E nessas dúvidas me dou conta de que a diversidade de cores pode ampliar a percepção visual, os modos de ver. As cores para pintar, imaginar, pensar uma (est)ética da docência a partir das práticas pedagógicas de Frida Kahlo apenas começam a produzir manchas e esboços de um desenho-caminho investigativo em construção. Com muitas perguntas e curiosidade sigo na perspectiva bricoladora que me auxilia a manchar, borrar, pintar com diferentes cores-conceitos as análises interpretativas e especulativas a que me proponho. Pois encanta-me compreender que podemos ver e interpretar de múltiplas maneiras um mesmo objeto, situação, experiência... Que as diferenças diversificam as formas de saber, ensinar, aprender em arte.

\section{Referências}

AGUIRRE, Imanol. Reflexividade e desafios na pesquisa com jovens produtores de cultura visual. In: MARTINS, Raimundo; TOURINHO, Irene. (Orgs.). Processos e práticas de pesquisa em cultura visual e educação. Santa Maria: Editora da UFSM, 2013. p. 291-320.

Cultura visual, política da estética e educação emancipadora. In: MARTINS, Raimundo; TOURINHO, Irene. (Orgs.). Educação da cultura visual: conceitos e contextos. Santa Maria: Editora da UFSM, 2011. p. 69-111.

CASTELO BRANCO, Guilherme. Anti-individualismo e vida artista. In: VASCONCELLOS, Jorge. Arte, vida e política: ensaios sobre Foucault e Deleuze. Rio de Janeiro: Edições LCV, 2010. p. 28-37.

COMISARENCO, Dina. Paredes olvidadas: el muralismo feminino (1930-1970). In: OLMOS, Gabriela. (Coord.). Libros pintados: murales de la Ciudad de México. Ciudad de México: Artes de México, 2015. p. 151-199. 
DUBERNARD, Luis Everaert. El Coyoacán de Frida Kahlo. In: KAISER, Federico Rubli. (Coord.). La Casa Azul de Frida. Ciudad de México: Chapa, 2007. p. 76-113.

FOUCAULT, Michel. A coragem da verdade: o governo de si e dos outros II: Curso no Collège de France (1983-1984). São Paulo: WMF Martins Fontes, 2017. . Sobre a genealogia da ética: uma revisão do trabalho. In: DREYFUS, Hubert;

RABINOW, Paul. Michel Foucault, uma trajetória filosófica: para além do estruturalismo e da hermenêutica. Rio de Janeiro: Forense Universitária, 1995. p. 253-278.

FRANCO, María Teresa. Frida Kahlo: autorretrato en su tinta. In: CALDERÓN, Cándila Fernández. (Coord.). Frida de Frida. Ciudad de México: Instituto Nacional de Bellas Artes, 2007. p. 141-170.

FREIRE, Paulo. Pedagogia da autonomia: saberes necessários à prática educativa. São Paulo: Paz e Terra, 2007. 148 p.

FRIDA MAESTRA el arte al encuentro de la vida. Vídeo. Direção Luisa Riley. Realização Ariel García e Emilio Cantón. Produção La Casa de Atrás S.C. Canal 22, Televisión Metripolitana S.A. de C.V. CONACULTA. Museo Casa Estúdio Diego Rivera y Frida Kahlo. México, 2004.

HERNÁNDEZ, Josefina García; TRUJILLO, Hilda. (Coord.). Querido Doctorcito: Frida Kahlo y Leo Eloesser: Correspondencia. Ciudad de México: Fideicomiso Museos Diego Rivera - Frida Kahlo, 2007. 288 p.

HERRERA, Hayden. Frida: a biografia. São Paulo: Globo, 2015. 620 p.

JAIMES, Héctor. Tu hija Frida. Cartas a mamá: compilación, introducción y notas de Héctor Jaimes. Ciudad de México: Fideicomiso Museos Diego Rivera - Frida Kahlo. 2016. 207 p.

JUÁREZ, Saúl. Presentación. In: REYES, María Dolores; ZAVALA, Magdalena. (Coord.). Frida Maestra: un reencuentro con los Fridos. Ciudad de México: Museo Casa Estudio Diego Rivera y Frida Kahlo, 2005. p. 11.

KAHLO, Frida. El diario de Frida Kahlo: una nueva mirada. México: La Vaca Independiente, 2017.

KAHLO, Isolda. Frida Íntima. Bogotá: Ediciones Dipon, 2004. 256 p. 
KINCHELOE, Joe L.; BERRY, Kathleen S. Pesquisa em educação: conceituando a bricolagem. Porto Alegre: Artmed, 2007.

MÉXICO, Subdirección General de Educación e Investigación Artísticas, Dirección de Asuntos Académicos. Secretaria de Cultura, Instituto Nacional de Bellas Artes (INBA), Escuela Nacional de Pintura, Escultura y Grabado "La Esmeralda". Plan de Estudios de la Licenciatura en Artes Visuales, 2016/2017. Disponível em: $<$ https://docs. wixstatic.com/ugd/d50bce 1fcf6b4061d74c1399e6124f2d24b26c.pdf $>$. Acesso em 11 mar. 2018.

MÉXICO, Subdirección General de Educación e Investigación Artísticas, Dirección de Asuntos Académicos. Secretaria de Cultura, Instituto Nacional de Bellas Artes (INBA), Escuela Nacional de Pintura, Escultura y Grabado "La Esmeralda". Plan de Estudios de la Licenciatura en Docencia de las Artes, 2016/2017. Disponível em: $<$ https://docs.wixstatic.com/ugd/d50bce da532b2fd39d4b7aa3b7aa8171ec4057.p df>. Acesso em 11 mar. 2018.

MONROY, Guillermo. El oficio de pintar. In: OROZCO, Leticia López. Revista Crónicas. No Especial. Tercer Encuentro Internacional de Pintura Mural: Creación, Investigacuión y Restauración Muros frente a Muros. México: Instituto de Investigaciones Estéticas de la Universidad Nacional Autónoma de México (UNAM), 2012. p. 261-277.

. Homenaje de un pintor a Frida Kahlo a los 22 años de su muerte. In: Jornal Excelsior, Cidade do México, 17 de julho, 1976. p. 08.

MORENO, Jorge Morales. Notas para una historia crítica de "La Esmeralda": la cuestión de sus orígenes (1927-1943). Discurso Visual, Revista de Artes Visuales, Tercera época, n. 36. Julio/Diciembre 2015. Ciudad de México: Centro Nacional de Investigación, Documentación y Información de Artes Plásticas. p. 07-42.

RANCIÈRE, Jacques. A partilha do sensível: estética e política. São Paulo: Editora 34, 2014. $72 \mathrm{p}$.

REYES, María Dolores. Frida Kahlo y sus alumnos. In: REYES, María Dolores; ZAVALA, Magdalena. (Coord.). Frida Maestra: un reencuentro con los Fridos. Ciudad de México: Museo Casa Estudio Diego Rivera y Frida Kahlo, 2005. p. 17-23.

RIVERA, Diego. Frida Kahlo y el arte mexicano. In: LOZANO, Luis-Martín. (Coord.). Frida Kahlo. Ciudad de México: Landucci, 2007. p. 233-235.

ROCHA, Thereza. Por uma docência artista com dança contemporânea. In: GONÇALVES, Thaís; BRIONES, Héctor. (Orgs.). Docência-artista do artistadocente: Seminário Dança Teatro Educação. Fortaleza: Expressão, 2012. p. 32-49. TIBOL, Raquel. Frida Kahlo en su luz más íntima. Ciudad de México: Lumen, 2005. $261 \mathrm{p}$.

Frida Kahlo an open life. United States of America: Editorial Oasis, 1993.

Revista Digital do LAV - Santa Maria - vol. 11, n. 1, p. 54-82- jan./abr. 2018 ISSN 1983 - 7348 http://dx.doi.org/10.5902/1983734831479 
Frida Kahlo: crónica, testimonios y aproximaciones. México D. F.: Ediciones de Cultura Popular, 1977.

ZAMORA, Martha. Frida: el pincel de la angustia. Ciudad de México: Preprensa Digital, 2015. 409 p.

ZAVALA, Magdalena. Una complicidad eterna. In: REYES, María Dolores; ZAVALA, Magdalena. (Coord.). Frida Maestra: un reencuentro con los Fridos. Ciudad de México: Museo Casa Estudio Diego Rivera y Frida Kahlo, 2005. p. 25-53.

\footnotetext{
' Odailso Sinvaldo Berté é professor do Curso de Licenciatura em Dança da Universidade Federal de Santa Maria, cursa Pós-Doutorado no Departamento de Arte da Universidad Iberoamericana Ciudad de México, é Doutor em Arte e Cultura Visual, UFG (2015), Mestre em Dança, UFBA (2011), Especialista em Dança, UNESPAR/FAP (2099) e Licenciado em Filosofia, UPF (2002). Lidera o Grupo de Estudos Laboratório Investigativo de Criações Contemporâneas em Dança (LICCDA), UFSM. Autor dos livros Dança Contempop: corpos, afetos e imagens (mo)vendo-se (2015) e O movimento criativo e pedagógico de Frida Kahlo (2018), ambos publicados pela Editora da UFSM.
}

Como citar esse artigo:

BERTE, Odailso Sinvaldo. A professora Frida Kahlo: cores para uma (est)ética da docência. Revista Digital do LAV, Santa Maria: UFSM, v. 11, n. 1, p. 54-82, jan./abr. 2018.

Enviado em: 10 de março de 2018.

Aprovado em: 31 de março de 2018. 